\title{
Moonlight and shelter cause differential seed selection and removal by rodents
}

\author{
Ramón Perea, Rocío González, Alfonso San Miguel, Luis Gil ${ }^{*}$ \\ Departamento de Silvopascicultura, ETSI de Montes, Universidad Politécnica de Madrid
}

Keywords:

Apodemus sylvaticus

foraging ecology

predation risk

Quercus

scatter hoarding

seed size

wood mouse
Various environmental factors may influence the foraging behaviour of seed dispersers which could ultimately affect the seed dispersal process. We examined whether moonlight levels and the presence or absence of rodent shelter affect rodent seed removal (rate, handling time and time of removal) and seed selection (size and species) among seven oak species. The presence or absence of safe microhabitats was found to be more important than moonlight levels in the removal of seeds. Bright moonlight caused a different temporal distribution of seed removal throughout the night but only affected the overall removal rates in open microhabitats. Seeds were removed more rapidly in open microhabitat (regardless of the moon phase), decreasing the time allocated to seed discrimination and translocation. Only in open microhabitats did increasing levels of moonlight decrease the time allocated to selection and removal of seeds. As a result, a more precise seed selection was made under shelter, owing to lower levels of predation risk. Rodent ranking preference for species was identical between full/new moon in shelter but not in open microhabitats. For all treatments, species selection by rodents was much stronger than size selection. Nevertheless, heavy seeds, which require more energy and time to be transported, were preferentially removed under shelter, where there is no time restriction to move the seeds. Our findings reveal that seed selection is safety dependent and, therefore, microhabitats in which seeds are located (sheltered versus exposed) and moonlight levels in open areas should be taken into account in rodent food selection studies.
Seed removal is an important step in the dispersal mechanism of animal-dispersed plants.

Most plants produce seeds that are available for different guilds of seed foragers. Some guilds are known to consume the whole seed leading to seed death (predators), whereas others can also act as effective seed dispersers (Herrera 2002). Scatter-hoarding rodents are known as one of the main guilds of seed dispersers (Xiao et al. 2004; Den Ouden et al. 2005; Steele et al. 2007; Briggs et al. 2009). Thus, the hoarding behaviour of some rodents is thought to increase the probability of seedling recruitment by storing seeds in a suitable site for germination (Soné \& Kohno 1996; Vander Wall 2001; Gómez et al. 2008; Perea et al. 2011a).

Rodents show preferences for certain seeds, mostly in relation to seed size, insect infestation and nutritional properties (Steele et al. 1996; Pons \& Pausas 2007a; Wang \& Chen 2008, 2009). As a result, rodent seed preferences cause a differential seed selection which may produce changes in seed dispersal rates (Vander Wall 2001; Xiao et al. 2005), mast seeding dynamics (Hoshizaki \& Hulme 2002) or even plant species composition (Janzen 1971). However,

\footnotetext{
* Correspondence: L. Gil, Departamento de Silvopascicultura, ETSI de Montes, Universidad Politécnica de Madrid, Ciudad Universitaria s/n, 28040 Madrid, Spain. E-mail address: luis.gil@upm.es (L. Gil).
}

seed selection may depend not only on intrinsic seed characteristics but also on environmental factors, which remain largely unexplored. Those factors that affect rodent behaviour will also involve changes in seed dispersal activity and, therefore, will have important implications for plant regeneration and ecosystem dynamics. Predation risk while foraging is a crucial aspect determining the behavioural responses of seed-dispersing rodents. Moon luminescence and the absence of cover impose an important increment in predation risk and strongly modify rodent behaviour (Díaz 1992; Kotler et al. 2010). Despite the key ecological roles played by seed-dispersing animals, the relative importance of these two environmental factors on seed selection and removal has not been fully explored.

There is evidence that bright moonlight increases levels of predation risk and, thus, reduces overall activity of nocturnal rodents (Blair 1943; Kaufman \& Kaufman 1982; Kotler 1984; Travers et al. 1988; Díaz 1992; Kotler et al. 2010). Consequently, to reduce predation risk, rodents select safe habitats and microhabitats when foraging (Sih 1980; Bowers \& Dooley 1993; Kotler et al. 2002; Díaz et al. 2005; Ylönen \& Brown 2007). One of the most common shelters is provided by shrub cover where rodents can forage and feed (Manson \& Stiles 1998; Muñoz et al. 2009). In addition, foragers try to balance foraging activity and safety by 
spending less time under high levels of predation risk (Lima \& Dill 1990).

As rodent activity varies depending upon vegetation structure and levels of moonlight, the removal and selection of seeds are likely to differ in response to these factors. Furthermore, seeds that are not removed rapidly by scatter-hoarding rodents will be exposed to seed predators, which make the seeds inviable and decrease plant reproduction efficiency (Vander Wall 2001). Thus, the temporal distribution of rodent activity throughout the night might be an important factor determining seed fate. The behaviour of scatter-hoarding rodents with regard to shelter and moonlight may affect different aspects of seed removal (e.g. amount of seeds removed, removal speed, exact time of removal and seed selection) and, eventually, the seed fate and the dispersal process. Then, the need arises for a better understanding of the processes of seed selection and removal by addressing the behaviour of the main seed dispersers. In this study, we specifically tested whether moonlight levels and microhabitat (presence or absence of rodent shelter) affected (1) the number of visits by rodents to seed sources, (2) the temporal distribution of seed removal by rodents throughout the night, (3) the time allocated by each individual to selecting and removing a seed and (4) the seed selection (size and species) by rodents among seven oak species. Finally, we aimed to integrate the results obtained to understand better the dispersing behaviour of rodents and its possible consequences for the regeneration of mixed oak forests and woodlands.

\section{METHODS}

\section{Study Area}

The study area is located in the Iberian Peninsula, one of the regions in Europe where the genus Quercus shows its highest diversity (Gil et al. 1996). This study was conducted in a mixed oak forest composed of temperate and sub-Mediterranean oak species (Quercus pyrenaica, Quercus petraea and Quercus robur). The forest is located in the Ayllón mountain range in central Spain $\left(3^{\circ} 30^{\prime} \mathrm{W}, 41^{\circ} 07^{\prime} \mathrm{N}\right.$, Madrid province), at $1400 \mathrm{~m}$ above sea level, in a sub-Mediterranean climate with $958 \mathrm{~mm}$ annual rainfall and a 2-month summer dry season. Other oak species (Quercus ilex, Quercus suber, Quercus faginea and Quercus coccifera) co-occur in proximate drier and lower areas within the same province (Table 1). According to previous parentage analyses performed with genetic markers (nSSRs), most tree offspring locations in the study area are the outcome of secondary acorn dispersal movements (Valbuena-Carabaña et al. 2005). In European oak forests, wood mice, Apodemus sylvaticus, are one of the main acorn removers as well as effective scatter-hoarders of acorns, playing an important role in the natural regeneration of oaks (Den Ouden et al. 2005; Pulido \& Díaz 2005; Perea et al. 2011a).

\section{Seed Removal Experiment}

Four sites were randomly established within the 12 stands of the study area. The approximate centre of the stand was used as the site location. Sites were at least $150 \mathrm{~m}$ apart to avoid overlapping sites and to ensure statistical spatial independence. Each site contained two acorn supply stations: one under dense shrub cover (more than $2 \mathrm{~m}$ diameter) and one under no shrub cover (only grasses and litter). Stations at each site were located $5-10 \mathrm{~m}$ from each other. Stations were built with wire mesh (square openings of $1.2 \mathrm{~cm}$ ) in a cubic shape ( $50 \times 50 \mathrm{~cm}$ and $3 \mathrm{~cm}$ high), to exclude removers other than small mammals. Eight digital video cameras with night vision and motion detection (Leaf River IR-5, $5 \mathrm{MP}$ ) were used simultaneously (one camera in each supply station). Each video recording lasted $30 \mathrm{~s}$. Experiments took place for 4 months, from May 2009 to August 2009. We used this period outside autumn (when the acorn drop period occurs) to avoid natural acorn availability interfering in the removal and selection behaviour of rodents (Pons \& Pausas 2007a) and outside winter because wood mice activity in this period is mostly driven by temperature (when below $2-4^{\circ} \mathrm{C}$ ) rather than moonlight (Wolton 1983). Each month had two trials, one at full moon and one at new moon. Each trial lasted 3 consecutive nights, from 1 night before full/ new moon to 1 night after full/new moon. Each supply station contained 70 acorns for each trial with no acorn replacement during the trial. Seven oak species were used (Table 1 ) with 10 acorns per species in each supply station. A total of 4480 acorns were weighed, numbered with waterproof ink and offered to the rodents (7 species $\times 10$ acorns $\times 8$ supply stations $\times 4$ months $\times 2$ trials per month). Some seeds were collected in the study area or nearby locations and others were provided by the staff members of the 'El Serranillo' nursery (Guadalajara, central Spain). Date, time, rodent species and number of individuals were obtained from each video recording. Time spent in selecting and removing each acorn was measured for each individual. Every day during the trials, we revisited the stations and noted the identification number of each remaining acorn since we could not identify which seed was removed during the recordings.

\section{Small Mammal Trapping}

Live trapping of small mammals was conducted at each site on 3 consecutive nights. Trapping periods started right after each acorn removal trial (eight periods). Trapping stations were located according to a quadrangular $3 \times 3$ grid, with $15 \mathrm{~m}$ between stations. Each station had two Sherman traps $(8 \times 9 \mathrm{~cm}$ and $23 \mathrm{~cm}$ high), so that sampling effort was 54 trap-nights per site and trial (216 trap-nights per trapping period). Traps were covered with leaf litter to provide shelter and weather insulation and were baited with acorns and sunflower seeds. Bedding was provided (dry leaves) and changed every time an animal was captured. No water was provided since wood mice usually obtain their water needs from food (Hansson 1971). Traps were opened at dusk and checked

Table 1

Main characteristics of the oak species studied

\begin{tabular}{|c|c|c|c|c|}
\hline $\begin{array}{l}\text { Oak species } \\
\text { (Quercus sp.) }\end{array}$ & $\begin{array}{l}\text { Acorn weight } \\
\text { (mean } \pm \mathrm{Cl} \text { g) }\end{array}$ & Climate & Morphology & $\begin{array}{l}\text { Co-occurring } \\
\text { species }\end{array}$ \\
\hline 1. Q. ilex & $3.68 \pm 0.09$ & Mediterranean & Evergreen sclerophyllous tree & $2,3,4,5$ \\
\hline 2. Q. suber & $5.68 \pm 0.15$ & Mediterranean & Evergreen sclerophyllous tree & $1,3,4,5$ \\
\hline 3. Q. coccifera & $3.10 \pm 0.13$ & Mediterranean & Evergreen sclerophyllous shrub & $1,2,4,5$ \\
\hline 4. Q. faginea & $2.56 \pm 0.09$ & Sub-Mediterranean & Semideciduous tree & $1,2,3,5,6$ \\
\hline 5. Q. pyrenaica & $4.82 \pm 0.09$ & Sub-Mediterranean & Semideciduous tree & $1,2,3,4,6$ \\
\hline 6. Q. petraea & $3.89 \pm 0.07$ & Temperate & Deciduous tree & $4,5,7$ \\
\hline 7. Q. robur & $4.12 \pm 0.09$ & Temperate & Deciduous tree & 5,6 \\
\hline
\end{tabular}

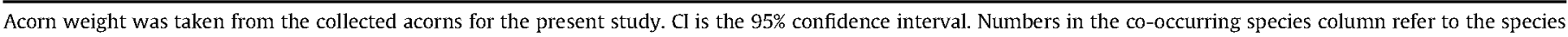
number in the first column, showing the most common mixed oak ecosystems. 
every morning (0800 hours). Thus, animals remained no longer than 1 night inside the trap. We did not open the traps in advance to accustom the rodents because live trapping was regularly conducted at the sites (March and October of each year since 2007). Captured individuals were identified to species, marked with numbered metal ear tags and then released at the point of capture. Ear tags were purchased from the National Band and Tag Company (Newport, KY, U.S.A.; type 1005-1 for small mammals; approximately $7 \mathrm{~mm}$ long). A topical antiseptic was applied on the ear puncture to prevent possible infections. All rodents that were recaptured looked healthy. Individuals that were pregnant when first captured were lactating when recaptured and the number of captures increased throughout the experiment, so that no adverse effects on litters or the rodent population were found. Permits for live trapping were obtained from the Department of Environment, regional Government of Madrid (Spain).

\section{Data Analysis}

Small mammal density for each site and trapping season could not be estimated by capture-mark-recapture methods because of the low number of captures. Generalized linear mixed models (GLMM) were used to explain the number of captures (response variable, Poisson error family). Moon phase was the fixed effect and the random effects structure was month nested within site.

We used multivariate modelling (various combinations of variables) and model comparison by using the Akaike information criterion (AIC). We first fitted the maximal model, containing all the explanatory variables. By using a model-averaging approach with all possible models (Anderson 2008), we established the importance of each variable. For model comparison and averaging we used the dredge function within the 'MuMIn' package of $\mathrm{R} 2.12 .2$ software (www.r-project.org). First, we used a linear mixed model (LMM) to analyse whether moonlight and microhabitat affected the time of seed removal by rodents. Response variable was the number of minutes spent between dusk and the time at which each rodent was recorded at the supply station. Fixed effects of the maximal model were moon phase (full moon versus new moon) and microhabitat (shrub versus open). Random effects were those considered in the nested structure (night nested within month and month nested within site). Second, we analysed the influence of moon phase and microhabitat on rodent activity by performing the same model as above with number of videos per night as the response variable. Third, we used another LMM to analyse whether different levels of moonlight (brightness) throughout the night affected the activity of rodents. We took the number of video recordings containing rodents as the response variable and moonlight brightness as the fixed effect. Moonlight brightness was estimated as a proportion of the maximum brightness, varying from 0 (total darkness, before moonrise and after moonset) to 1 (maximum illumination, when the full moon, on a clear night, is at its highest position in the sky). Time of moonrise and moonset were obtained from a moon calendar. Thus, for each video recording we obtained a value of moonlight brightness (from 0 to 1 ) according to the exact night ( 1 night before full moon, during full moon or 1 night after full moon), the position of the moon in the sky and the average cloudiness of the night. Data for the overall reduction of the moonlight brightness on the nights before and after full moon were obtained from El Tiempo, Foreca Ltd, AEMET, Spain. Time at which the moon was at the highest position for each night (maximum nightly illumination) was obtained as the average time between moonrise and moonset. We used linear interpolation between moonrise illumination (0\%) and highest position (100\%) to calculate an hourly percentage of maximum illumination for each night. Moonlight loss caused by clouds was estimated for each night by measuring the daylight loss during the $3 \mathrm{~h}$ before dusk and the $3 \mathrm{~h}$ after dawn of that night, with the use of a Pyranometer sensor (LI-COR LI-200). We obtained a mean value of daylight loss as a percentage from these $6 \mathrm{~h}$ of data. Finally, we assumed the mean value of daylight loss to be equivalent to moonlight loss. Random effects were the same as in the model above. Finally, to analyse whether acorn handling time is affected by moon phase and microhabitat we measured the time (s) that a rodent spent selecting and removing an acorn in the video recordings. Fixed effects in the LMM were moon phase and microhabitat with the same structure of random effects. We also used linear regressions to see whether handling time was correlated with moonlight brightness.

To analyse acorn removal and selection we ran GLMMs. We always used the same binary response variable (seed removed or not). For the acorn removal analysis we included microhabitat, moon phase, acorn weight and seed species as fixed effects. Random effects were considered in the same structure as in the models above. For the acorn selection analysis we used only the first day of each trial (when all seeds were available). Species were regrouped (factor levels reduction) to classify the oak species in a significant order of preference by rodents for each combination of microhabitat and moon phase. The group of acorns (acorns that were placed together on the same day and supply station) and acorn size were included as random effects.

\section{RESULTS}

All captured individuals were wood mice. The percentage of captures that occurred during full moons was lower $(42 \% ; N=36)$ with 0.08 captures per trap-night than during new moons $(58 \%$; $N=50$ ) with 0.12 captures per trap-night, but no significant differences were found $(Z=-1.499, P=0.134)$. We obtained 2361 video recordings with rodents. In 97 video recordings, voles (Microtus sp.) were seen taking acorns to their burrows. The rest of the videos contained wood mice. Forty-seven videos (2.1\% of wood mouse videos) contained more than one wood mouse removing seeds at the same time (during the same video recording).

\section{Rodent Activity}

Full moon under no cover had the fewest videos and new moon under shelter the most (Table 2). Microhabitat showed the highest relative importance in the number of visits, followed by moon

Table 2

Summary of the activity of rodents for different moon phases and microhabitats

\begin{tabular}{|c|c|c|c|c|c|c|c|c|}
\hline \multirow[t]{3}{*}{ Microhabitat } & \multicolumn{8}{|c|}{ Moon phase } \\
\hline & \multicolumn{4}{|l|}{ Full moon } & \multicolumn{4}{|l|}{ New moon } \\
\hline & $\begin{array}{l}\text { No. of } \\
\text { visits (\%) }\end{array}$ & $\begin{array}{l}\text { No. of acorns } \\
\text { removed (\%) }\end{array}$ & $\begin{array}{l}\text { First } \\
\text { removal (min) }\end{array}$ & $\begin{array}{l}\text { Removal } \\
\text { time (min) }\end{array}$ & $\begin{array}{l}\text { No. of } \\
\text { visits (\%) }\end{array}$ & $\begin{array}{l}\text { No. of acorns } \\
\text { removed (\%) }\end{array}$ & $\begin{array}{l}\text { First } \\
\text { removal (min) }\end{array}$ & $\begin{array}{l}\text { Removal } \\
\text { time (min) }\end{array}$ \\
\hline Open & $191(8)$ & $437(11)$ & $81 \pm 65$ & $243 \pm 138$ & $285(12)$ & $858(22)$ & $211 \pm 133$ & $303 \pm 117$ \\
\hline Shelter & $882(37)$ & $1218(32)$ & $65 \pm 66$ & $244 \pm 142$ & $1003(43)$ & $1313(35)$ & $90 \pm 77$ & $203 \pm 118$ \\
\hline
\end{tabular}

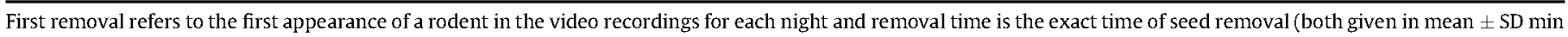
after dusk). 
phase (Table 3). Mean luminosity per night did not explain the number of visits by rodents $\left(R^{2}=-0.09, t=0.152, P=0.880\right)$. However, during the full moon nights, number of visits was well explained by the variable moonlight brightness (Fig. 1), with fewer visits for higher levels of moonlight.

\section{Removal Rates}

A total of 3829 acorns was removed (85.5\%) for the whole experiment. More seeds were removed under shelter in comparison to open areas for both full moon and new moon (Table 2). Acorn species and microhabitat are included in all models, indicating strong support (Table 4). Moon phase received lower relative importance (0.63) than microhabitat and acorn species (1.00). Acorn weight received weaker support with a relative importance of 0.34 . Moon phase affected seed removal in open microhabitats, with more seeds removed during the new moon (Table 2).

\section{Removal Time}

Only one model was considered plausible (Akaike weight equal to 1 ) when we analysed time to remove the first seed (first rodent appearance in each station). This model included both microhabitat and moon phase as explanatory variables. Both shelter and full moon reduced the mean time of first removal (Table 2). The contribution to the explained variance is higher for the moon phase (63.6\%) than the microhabitat (36.4\%).

Only one model was plausible (Akaike weight equal to 1) when we analysed the exact time at which acorns were removed throughout the night. This model included as predictors: microhabitat, moon phase and the interaction between them. Under shelter, acorns were removed earlier during the new moon than during the full moon (Fig. 2). However, in open areas, seeds were removed earlier during the full moon than during the new moon (Fig. 2).

\section{Handling Time}

Rodents spent proportionally more time under shelter to choose and remove a specific acorn for both full moon (median $=15.0 \mathrm{~s}$ ) and new moon (median $=18.5 \mathrm{~s}$ ) in comparison to open microhabitat (median $=9.6 \mathrm{~s}$ for full moon and $12.9 \mathrm{~s}$ for new moon). Moonlight brightness was negatively correlated with handling time in open microhabitats $\left(R^{2}=-0.28, t=3.677, P=0.001\right)$, but no significant correlation was found under cover $\left(R^{2}=0.007\right.$, $t=-0.698, P=0.485$ ).

\section{Seed Selection}

Acorn species was included in all acorn selection models, indicating strong support (Table 5). The relative importance of the

Table 3

Summary of the model ranking using Akaike information criterion (AIC) to test the variables affecting rodent activity

\begin{tabular}{llllll}
\hline $\begin{array}{l}\text { Model } \\
\text { ranking }\end{array}$ & Main effects & AIC & $k$ & $\Delta_{i}$ & $w_{i}$ \\
\hline 1 & $\begin{array}{l}\text { Moon phase+Microhabitat } \\
\text { +Moon phase*Microhabitat }\end{array}$ & 929.6 & 8 & 0.00 & 0.871 \\
2 & $\begin{array}{l}\text { Moon phase+Microhabitat } \\
3\end{array}$ & 933.9 & 7 & 4.28 & 0.102 \\
\hline
\end{tabular}

Models are based on the number of video recordings $(N=2354)$ for each camera-night ( $N=192$ observations). $\Delta_{i}$ is the delta weight (difference between the AIC for a given model and the best fitting model), $k$ is the number of estimated parameters and $w_{i}$ is the model selection probability (Akaike weights). All models are shown except those whose $w_{i}$ were zero. Relative variable importance (model averaging for all models): Microhabitat 1.00; Moon phase 0.97; Moon phase $\times$ Microhabitat: 0.87 .

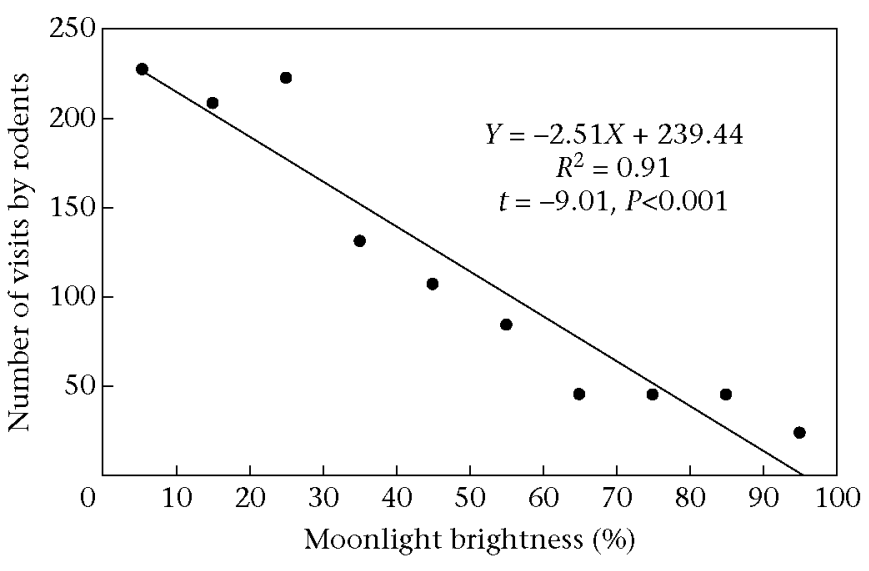

Figure 1. Number of visits by rodents in relation to moonlight brightness. Moonlight brightness is given as percentage of maximum illumination (highest position of the full moon in the sky in a cleat night). Data are for visits to open microhabitat.

variable acorn weight was 0.36 in comparison to acorn species (value of 1.00). Oak species were grouped (G1-G3), with each group containing those species that showed no significant differences in seed selection. Significant differences were only obtained between the species that belonged to different groups. We obtained more groups (more precise selection) under shelter than in open areas (Table 6). Differences in the order of species preference between microhabitats (shrub versus open) were only marginally significant $(Z=-1.778, P=0.075$; Table 6$)$. However, microhabitat showed significant interaction with seed size selection $(Z=1.679$, $P=0.043$ ), with larger seeds removed under shelter. Moon phase (full versus new) showed no significant interaction with both species selection $(Z=1.202, \quad P=0.230)$ and size selection $(Z=1.262, P=0.207)$. Moon phase revealed significant differences in species selection only when we considered the interaction between moon phase and microhabitat $(Z=-2.615, P=0.009)$. Thus, only in open microhabitat did seed preference differ in full and new moon (Table 6).

\section{DISCUSSION}

We have shown that moonlight and the presence of shelter are important factors that interact and affect not only rodent foraging activity and seed removal but also seed selection. However, microhabitat (sheltered versus exposed) was found to be a more relevant factor than moonlight in the removal and selection of seeds by rodents. Moonlight was a determinant factor only in open areas, causing a more rapid removal (less precise selection) and

\section{Table 4}

Summary of the model ranking using Akaike information criterion (AIC) to test the variables affecting acorn removal by rodents

\begin{tabular}{llllll}
\hline $\begin{array}{l}\text { Model } \\
\text { ranking }\end{array}$ & Main effects & AIC & $k$ & $\Delta_{i}$ & $w_{i}$ \\
\hline 1 & $\begin{array}{l}\text { Moon phase+Microhabitat+ } \\
\text { Acorn species }\end{array}$ & 2535.21 & 11 & 0.00 & 0.325 \\
2 & $\begin{array}{l}\text { Microhabitat+Acorn species } \\
3\end{array}$ & 2535.35 & 10 & 0.14 & 0.303 \\
4 & $\begin{array}{l}\text { Moon phase+Microhabitat+ } \\
\text { Acorn species+Acorn weight }\end{array}$ & 2536.24 & 12 & 1.03 & 0.194 \\
& $\begin{array}{l}\text { Microhabitat+Acorn species+ } \\
\text { Acorn weight }\end{array}$ & 2536.41 & 11 & 1.20 & 0.178 \\
\hline
\end{tabular}

Models are based on the number of seeds offered to rodents $(N=4480)$. $\Delta_{i}$ is the delta weight (difference between the AIC for a given model and the best fitting model), $k$ is the number of estimated parameters and $w_{i}$ is the model selection probability (Akaike weights). All models are shown except those whose $w_{i}$ were zero. Relative variable importance (model averaging for all models): Microhabitat 1.00; Acorn species 1.00; Moon phase: 0.63; Acorn weight: 0.24 . 


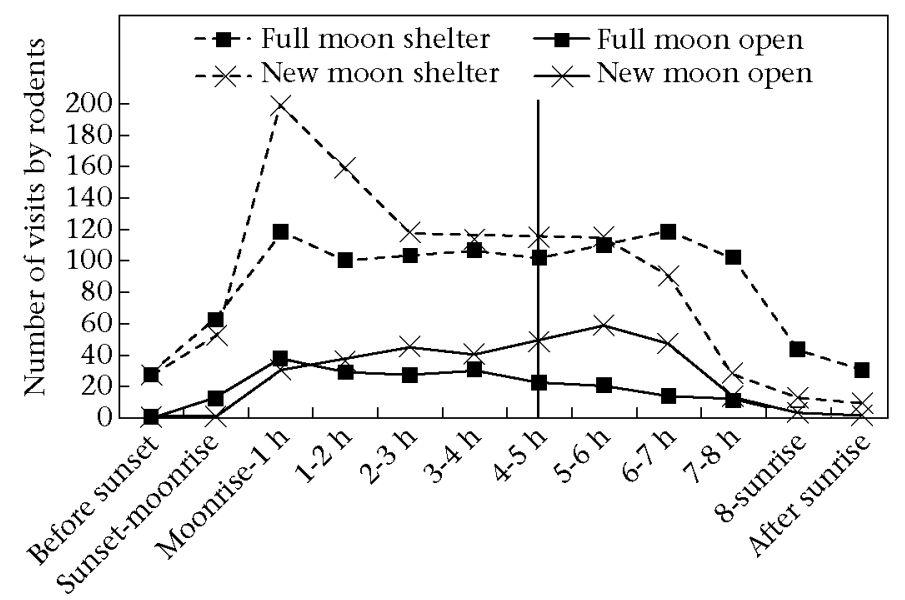

Time (hours after moonrise)

Figure 2. Number of visits by rodents throughout the course of the night for different microhabitats (open versus shelter) and moon phases (full versus new). The vertical black bar represents the time of maximum illumination.

a decrease in the overall removal rates. Thus, we demonstrated that rodent seed selection is safety dependent and not exclusively driven by seed properties (e.g. seed size).

\section{Rodent Removal Activity}

We found that shelter, provided by shrub cover, increased rodent activity, which is in agreement with other studies (Manson \& Stiles 1998; Den Ouden et al. 2005). Moonlight brightness affected rodent activity (Fig. 1) in open areas with more seeds removed under low levels of moonlight (caused by either cloudiness or lower positions of the moon in the sky). Thus, wood mice foraged less frequently under high levels of illumination, as also found by other studies (Kotler et al. 1991, 1994). Notwithstanding, this study revealed that the presence or absence of safe microhabitats was more important than moonlight levels in the removal of seeds. We found an important microhabitat effect, even during the new moon. However, other studies highlight the lack of microhabitat effect when rodents are foraging at moon phases other than full moon (Kotler et al. 2002). Our results confirm the idea that foraging costs are higher in open microhabitats, owing to higher predation risk (Kotler et al. 1991; Longland 1994; Den Ouden et al. 2005), and extend it to any moon phase, pointing out the importance of sheltered/exposed microhabitats over the moon phases. This strong association between shrub cover and removal rates differs from other studies (Díaz 1992), in which seed removal by wood mice in summer was evenly distributed across open and sheltered habitats, although this conclusion was not strongly supported because of the low seed removal rates.

Table 5

Summary of the model ranking using Akaike information criterion (AIC) for the acorn selection on the first day that rodents encountered the stations

\begin{tabular}{lllrll}
\hline $\begin{array}{l}\text { Model } \\
\text { ranking }\end{array}$ & Main effects & AIC & $k$ & $\Delta_{i}$ & $w_{i}$ \\
\hline 1 & Acorn species & 3498.91 & 9 & 0.00 & 0.631 \\
2 & Acorn species+ & 3499.98 & 10 & 1.07 & 0.369 \\
& Acorn weight & & & & \\
\hline
\end{tabular}

Models are based on the number of seeds offered to rodents $(N=4480) . \Delta_{i}$ is the delta weight (difference between the AIC for a given model and the best fitting model), $k$ is the number of estimated parameters and $w_{i}$ is the model selection probability (Akaike weights). All models are shown except those whose $w_{i}$ were zero. Relative variable importance (model averaging for all models): Acorn species 1.00; Acorn weight: 0.37 .
We also found that time allocated to acorn removal under shelter was not affected by increasing levels of moonlight. Only in open areas did moonlight brightness decrease the acorn handling time by rodents, probably because of higher predation exposure. This contradicts the 'higher requisite profit' model which suggests that foragers should be more selective when predation risk increases (Leaver \& Daly 2003). In contrast, this study agrees with the 'reduced finickiness' model, which predicts that foragers should be less selective (less handling time) when predation risk increases since selectivity requires more, and more intense, searching behaviour, prolonging exposure to risk (Crowley et al. 1991; Leaver \& Daly 2003).

\section{Temporal Distribution of Seed Removal}

Although intraspecific competition in rodents is higher under shelter (Hughes et al. 1994), we found that rodents first search for food in their preferred microhabitat (shelter), even during new moon and then move to open areas after depleting food supplies in shrubby areas. During the new moon there is no time restriction to foraging in open and unexplored areas if necessary. As a result, rodents can increase their foraging home range size because of lower predation risk, in agreement with Taylor (1988). However, during the full moon, seeds were removed more intensely in open areas during the first hours of the night (lower levels of moonlight) and then rodents moved gradually to covered areas which are the only safe microhabitat to forage in under high levels of moonlight. Thus, an increasing level of moonlight brightness is probably the main cause of the different temporal distribution of seed removal. We have shown that the interaction between microhabitat and moonlight affects the exact time at which seeds are removed and thus could also affect seed fate. Those seeds that are removed later by scatter-hoarders will have a higher probability of being preyed upon by seed predators (e.g. ungulates).

\section{Seed Selection}

We found that moonlight affected seed selection only in open microhabitats, with a less precise selection than in sheltered microhabitats. This could be explained by the decrease in seed handling time (higher predation risk) when rodents forage in moonlit open areas. Furthermore, these findings agree with the idea that in patches with fewer competitors (e.g. open microhabitats), a forager should behave more opportunistically (i.e. be less selective) whereas in patches with high competition, individuals should become more specialist, being more selective at first and more opportunistic when food availability decreases (Mitchell 1990; Kotler et al. 2002). In that way, moonlight brightness could be considered as an environmental factor that reduces competition in open areas and increases it in sheltered microhabitats.

Preferences for seeds of certain oak species might be related to chemical compounds such as oil, tannin and phenolic contents (Janzen 1971; Afzalrafii et al. 1992; Cantos et al. 2003; Cañellas \& San Miguel 2003). Pons \& Pausas (2007a) also found significant differences in acorn selection by rodents, with a decreasing preference for $Q$. ilex, $Q$. suber and $Q$. coccifera. In this study, differences between $Q$. ilex and $Q$. suber selection were found only under shelter, which means that species selection is affected by the microhabitat in which seeds are located. Rodents under shelter allocated more time to seed selection and could discriminate seeds more precisely, causing differential seed selection. In addition, large seeds were preferred over small ones only in the shelter microhabitat. Large seeds are more nutritious and are preferentially selected by rodents (Gómez 2004; Wang \& Chen 2009). However, the microhabitat in which seeds are found may have an effect on 
Table 6

Rodent acorn selection for different moon phases (full moon versus new moon) and different microhabitats (open versus shelter)

\begin{tabular}{|c|c|c|c|c|}
\hline & New moon & & Full moon & \\
\hline Open & $\begin{array}{l}\text { G1: Q. faginea }>\text { Q. ilex }>\text { Q. suber } \\
\text { G2: Q. pyrenaica }>\text { Q. petraea }> \\
\text { Q. robur }>\text { Q. coccifera }\end{array}$ & $\begin{array}{l}Z=6.185 \\
P<0.001\end{array}$ & $\begin{array}{l}\text { G1: Q. faginea }>\text { Q. ilex }>\text { Q. robur }>\text { Q. suber }> \\
\text { Q. petraea }>\text { Q. pyrenaica } \\
\text { G2: Q. coccifera }\end{array}$ & $\begin{array}{l}Z=-4.553 \\
P<0.001\end{array}$ \\
\hline Shelter & $\begin{array}{l}\text { G1: Q. ilex }>\text { Q. faginea } \\
\text { G2: Q. suber }>\text { Q. pyrenaica }> \\
\text { Q. petraea }>\text { Q. robur } \\
\text { G3: Q. coccifera }\end{array}$ & $\begin{array}{l}Z=-2.621 \\
P=0.009 \\
Z=4.804 \\
P<0.001\end{array}$ & $\begin{array}{l}\text { G1: Q. ilex }>\text { Q. faginea } \\
\text { G2: Q. suber }>\text { Q. pyrenaica }>\text { Q. petraea }>\text { Q. robur } \\
\text { G3: Q. coccifera }\end{array}$ & $\begin{array}{l}Z=-2.217 \\
P=0.027 \\
Z=2.262 \\
P=0.024\end{array}$ \\
\hline
\end{tabular}

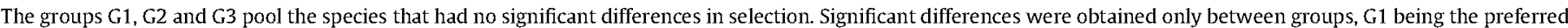
group and $\mathrm{G} 3$ the least preferred group. In each group, species are given in a decreasing order of preference.

size selection. In this regard, heavy seeds, which require more energy and time to be transported, were only preferentially removed under shelter, where there is a lower level of predation risk and no time restriction to moving the seeds. Thus, our findings reveal that seed selection is safety dependent and, therefore, microhabitats in which seeds are located (sheltered versus exposed) should be taken into account in rodent food selection studies.

Under the same conditions, species selection was stronger than size selection. Quercus faginea acorns (the smallest ones) were preferred over the heavy acorn species. Many studies assume that rodent preference for different species of acorns is mostly due to seed size (Pérez-Ramos \& Marañón 2008). Moreover, Wang \& Chen (2009) indicated that seed size is a decisive factor in seed choice and rodent hoarding behaviour, while nutrient and tannin content are less consistent. However, in this study we demonstrated that species selection by rodents is much stronger than size selection and thus differences in seed selection are not only driven by seed size. The same findings have been found for rodents selecting different fleshy fruited species (Perea et al. 2011b) as well as for other acorn foragers such as jays, Garrulus glandarius (Pons \& Pausas 2007b).

\section{Implications of Acorn Selection in Mixed Oak Ecosystems}

This study focused on the selection of seeds by rodents in natural conditions (e.g. competition among individuals), which allowed us to know which seeds were first removed and dispersed in the field. However, we could not assess intraspecific variation in seed selection because of our inability to identify individual rodents in the recordings (e.g. juveniles versus adults). The preference ranking for acorn species, provided in Table 6 , has important implications for oak regeneration. Acorns are recalcitrant seeds (intolerant to desiccation) that need to be buried as soon as possible to avoid predation (e.g. by ungulates), biotic damage (fungi and bacteria) or dehydration (Lambert 2002). In that way, rapid removal (because of acorn preference) will decrease the exposure to negative agents. Consequently, seeds that are preferred by scatter-hoarders will have a higher probability of surviving than nonpreferred seeds, which will remain exposed on the ground. Although some acorns will be retrieved and preyed upon by rodents, many others will be hoarded and escape predation (Pulido \& Díaz 2005; Gómez et al. 2008; Perea et al. 2011a). The relative abundance of acorns versus rodents will play an important role, with more seeds dispersed and predated less under high seed/ rodent ratios (Theimer 2004; Zhang et al. 2008). Masting, a common phenomenon in oak species, might also determine whether preferred acorns will be favoured or not. Thus, in low seed production years, acorns selected by rodents might suffer higher recovery and, therefore, higher predation, whereas the nonpreferred seeds would have a higher caching rate. Nevertheless, the balance between seed predation and effective dispersal needs further attention to understand fully the ecological consequences of acorn selection in the regeneration and species composition of mixed oak landscapes.

\section{Acknowledgments}

We are indebted to the staff members of the 'El Serranillo' nursery for acorn collection and storage. We thank Jesús Alonso for his fieldwork assistance. Marco Girardello provided valuable comments in data analysis. R.P. is supported by a Ph.D. grant from Universidad Politécnica de Madrid. This study was funded by the Comunidad Autónoma de Madrid and the Project AGL2006-00813 of the Spanish CICYT.

\section{References}

Afzalrafii, Z., Dodd, R. S. \& Pelleau, Y. 1992. Mediterranean evergreen oak diversity: morphological and chemical variation of acorns. Canadian Journal of Botany, 70, 1459-1466.

Anderson, D. R. 2008. Model Based Inference in the Life Sciences: a Primer on Evidence. New York: Springer Verlag.

Blair, W. F. 1943. Activities of the Chihuahua deer-mouse in relation to light intensity. Journal of Wildlife Management, 7, 92-97.

Bowers, M. A. \& Dooley, J. L. 1993. Predation hazard and seed removal by small mammals: microhabitat versus patch scale effects. Decologia, 94, 247-254.

Briggs, J. S., Vander Wall, S. B. \& Jenkins, S. 2009. Forest rodents provide direct dispersal of Jeffrey pine seeds. Ecology, 90, 675-687.

Cantos, E., Espin, J. C., Lopez-Bote, C., De la Hoz, L., Ordonez, J. A. \& TomasBarberan, F. A. 2003. Phenolic compounds and fatty acids from acorns (Quercus spp.), the main dietary constituent of free-ranged Iberian pigs. Journal of Agricultural and Food Chemistry, 51, 6248-6255.

Cañellas, I. \& San Miguel, A. 2003. La Coscoja (Quercus coccifera L.): Ecología, Caracteristicas y Usos. Madrid: INIA.

Crowley, P., Travers, S., Linton, M., Cohn, S., Sih, A. \& Sargent, C. 1991. Mate density, predation risk, and the seasonal sequence of mate choice: a dynamic game. American Naturalist, 137, 567-596.

Den Ouden, J., Jansen, P. A. \& Smit, R. 2005. Jays, mice and oaks: predation and dispersal of Quercus robur and Q. petraea in North-western Europe. In: Seed Fate (Ed. by P. M. Forget, J. Lambert, P. Hulme \& S. B. Vander Wall), pp. 223-240. Wallingford: $\mathrm{CAB}$ International.

Díaz, M. 1992. Rodent seed predation in cereal crop areas of central Spain: effects of physiognomy, food availability, and predation risk. Ecography, 15, 77-85.

Díaz, M., Torre, I., Peris, A. \& Tena, L. 2005. Foraging behavior of wood mice as related to presence and activity of genets. Journal of Mammalogy, 86, 1178-1185.

Gil, L., Jiménez, M. P. \& Díaz-Fenández, P. M. 1996. Quercus complex in Spain: an overview of its present state. In: Inter-and Intraspecific Variation in European Oaks: Evolutionary Implications and Practical Consequences (Ed. by A. Kremer \& H. Mühs), pp. 295-318. Brussels: Office for Official Publications of the European Communities.

Gómez, J. M. 2004. Bigger is not always better: conflicting selective pressures on seed size in Quercus ilex. Evolution, 58, 71-80.

Gómez, J. M., Puerta-Piñeiro, C. \& Schupp, E. W. 2008. Effectiveness of rodents as local seed dispersers of Holm oaks. Oecologia, 155, 529-537.

Hansson, L. 1971. Small rodent food, feeding and population dynamics: a comparison between granivorous and herbivorous species in Scandinavia. Oikos, 22 $183-198$ 
Herrera, C. M. 2002. Seed dispersal by vertebrates. In: Plant-Animal Interactions. An Evolutionary Approach (Ed. by C. M. Herrera \& O. Pellmyr), pp. 185-208. Oxford: Blackwell Science.

Hoshizaki, K. \& Hulme, P. E. 2002. Mast seeding and predator-mediated indirect interactions in a forest community: evidence from post-dispersal fate of rodent-generated caches. In: Seed Dispersal and Frugivory: Ecology, Evolution and Conservation (Ed. by D. J. Levey, W. R. Silva \& M. Galetti), pp. 227-239. New York: CAB International.

Hughes, J. J. Ward, D. \& Perrin, M. R. 1994. Predation risk and competition affect habitat selection and activity of Namib desert gerbils. Ecology, 75, 1397-1405.

Janzen, D. H. 1971. Seed predation by animals. Annual Review of Ecology and Systematics, 2, 465-492.

Kaufman, D. W. \& Kaufman, G. A. 1982. Effect of moonlight on activity and microhabitat use by Ord's kangaroo rat (Dipodomys ordii). Journal of Mammalogy, 63, 309-312.

Kotler, B. P. 1984. Predation risk and the structure of desert rodent communities. Ecology, 65, 689-701.

Kotler, B. P., Brown, J. S. \& Hasson, O. 1991. Factors affecting gerbil foraging behavior and rates of owl predation. Ecology, 72, 2249-2260.

Kotler, B. P., Ayal, Y. \& Suhach, A. 1994. Effects of predatory risk and resource renewal on the timing of foraging activity in a gerbil community. Oecologia, 100, 391-396.

Kotler, B. P., Brown, J.S., Dall, S. R. X., Gresser, S., Ganey, D. \& Bouskila, A. 2002. Foraging games between gerbils and their predators: temporal dynamics of resource depletion and apprehension in gerbils. Evolutionary Ecology Research, 4, 495-518.

Kotler, B. P., Brown, J., Mukherjee, S., Berger-Tal, O. \& Bouskila, A. 2010. Moonlight avoidance in gerbils reveals a sophisticated interplay among time allocation, vigilance and state-dependent foraging. Proceedings of the Royal Society B, 277, 1469-1474.

Lambert, J. E. 2002. Exploring the link between animal frugivory and plant strategies: the case of primate fruit-processing and post-dispersal seed fate. In: Seed Dispersal and Frugivory: Ecology, Evolution and Conservation (Ed. by D. J. Levey, W. R. Silva \& M. Galetti), pp. 365-379. New York: CAB International.

Leaver, L. A. \& Daly, M. 2003. Effect of predation risk on selectivity of heteromyid rodents. Behavioral Processes, 64, 71-75.

Lima, S. L. \& Dill, L. 1990. Behavioral decisions made under risk of predation: a review and prospectus. Canadian Journal of Zoology, 68, 619-640.

Longland, W. S. 1994. Effect of artificial bush canopy and illumination on seed patch selection by heteromyid rodents. American Midland Naturalist, 132, 82-90.

Manson, R. H. \& Stiles, E. W. 1998. Links between microhabitat preferences and seed predation by small mammals in old fields. Oikos, 82, 37-50.

Mitchell, W. A. 1990. An optimal-control theory of diet selection: the effects of resource depletion and exploitative competition. Oikos, 58, 16-24.

Muñoz, A., Bonal, R. \& Díaz, M. 2009. Ungulates, rodents, shrubs: interactions in a diverse Mediterranean ecosystem. Basic and Applied Ecology, 10, 151-160.

Perea, R., San Miguel, A. \& Gil, L. 2011a. Leftovers in seed dispersal: ecologica implications of partial seed consumption for oak regeneration. Journal of Ecology, 99, 194-201.

Perea, R., San Miguel, A. \& Gil, L. 2011b. Disentangling the factors controlling fruit and seed removal by rodents in temperate forests. Seed Science Research, 21, 227-234

Pérez-Ramos, I. M. \& Marañón, T. 2008. Factors affecting post-dispersal seed predation in two coexisting oak species: microhabitat, burial and exclusion of large herbivores. Forest Ecology and Management, 255, 3506-3514.
Pons, J. \& Pausas, J. G. 2007a. Rodent acorn selection in a Mediterranean oak landscape. Ecological Research, 22, 535-541.

Pons, J. \& Pausas, J. G. 2007b. Not only size matters: acorn selection by the European jay (Garrulus glandarius). Acta Oecologica, 31, 353-360.

Pulido, F. J. \& Díaz, M. 2005. Regeneration of a Mediterranean oak: a whole-cycle approach. Ecoscience, 12, 92-102.

Sih, A. 1980. Optimal behaviour: can foragers balance two conflicting demands? Science, 210, 1041-1043.

Soné, K. \& Kohno, A. 1996. Application of radiotelemetry to the survey of acorn dispersal by Apodemus mice. Ecological Research, 11, 187-192.

Steele, M. A., Hadj-Chikh, L. Z. \& Hazeltine, J. 1996. Caching and feeding decisions by Sciurus carolinensis: responses to weevil-infested acorns. Journal of Mammalogy, 77, 305-314.

Steele, M. A., Carlson, J. E., Smallwood, P. D., McEuen, A. B., Contreras, T. A. \& Terzaghi, W. B. 2007. Linking seed and seedling shadows: a case study in the oaks (Ouercus). In: Seed Dispersal: Theory and its Application in a Changing World (Ed. by A. J. Denis, R. J. Green, E. W. Schupp \& D. A. Westcott), pp. 322-339. Wallingford: $C A B$ International.

Taylor, R. J. 1988. Territory size and location in animals with refuges influence predation risk. Evolutionary Ecology, 2, 95-101.

Theimer, T. C. 2004. Rodent scatterhoarders as conditional mutualists. In: Seed Fate (Ed. by P. M. Forget, J. Lambert, P. Hulme \& S. B. Vander Wall), pp. 283-295. Wallingford: $\mathrm{CAB}$ International.

Travers, S. E., Kaufman, D. W. \& Kaufman, G. A. 1988. Differential use of experimental habitat patches by foraging Peromyscus maniculatus on dark and bright nights. Journal of Mammalogy, 69, 869-872.

Valbuena-Carabaña, M., González Martínez, S. C., Sork, V. L., Collada, C., Soto, A. Goicoechea, P. G. \& Gil, L. 2005. Gene flow and hybridisation in a mixed oak forest (Quercus pyrenaica Willd. and Quercus petraea (Matts.) Liebl.) in central Spain. Heredity, 95, 457-465.

Vander Wall, S. B. 2001. The evolutionary ecology of nut dispersal. Botanical Review, 67, 74-117.

Wang, B. \& Chen, J. 2008. An experiment using artificial 'seeds'. Acta Oecologica, 34 379-385.

Wang, B. \& Chen, J. 2009. Seed size, more than nutrient or tannin content, affects seed caching behavior of a common genus of Old World rodents. Ecology, 90 , 3023-3032.

Wolton, R. J. 1983. The activity of free-ranging wood mice Apodemus sylvaticus. Journal of Animal Ecology, 52, 781-794.

Xiao, Z. S., Zhang, Z. B. \& Wang, Y. S. 2004. Dispersal and germination of big and small nuts of Quercus serrata in a subtropical broad-leaved evergreen forest. Forest Ecology and Management, 195, 141-150.

Xiao, Z. S., Zhang, Z. B. \& Wang, Y. S. 2005. Effects of seed size on dispersal distance in five rodent-dispersed fagaceous species. Acta Decologica, 28 221-229.

Ylönen, H. \& Brown, J. S. 2007. Fear and the foraging, breeding and sociality in rodents. In: Rodent Societies (Ed. by J. O. Wolff \& P. W. Sherman), pp. 328-341. Chicago: University of Chicago Press.

Zhang, H. M., Cheng, J. R., Xiao, Z. S. \& Zhang, Z. B. 2008. Effects of seed abundance on seed scatter-hoarding of Edward's rat (Leopoldamys edwardsi Muridae) at the individual level. Oecologia, 158, 57-63. 